What's Wrong with Democracy? 
This page intentionally left blank 


\section{What's Wrong with}

Democracy?

FROM ATHENIAN PRACTICE TO AMERICAN WORSHIP

Loren J. Samons II

UNIVERSITY OF CALIFORNIA PRESS BERKELEY LOS ANGELES LONDON 
University of California Press

Berkeley and Los Angeles, California

University of California Press, Ltd.

London, England

(C) 2004 by the Regents of the University of California

Library of Congress Cataloging-in-Publication Data

Samons, Loren J.

What's wrong with democracy? : from Athenian practice to American worship / Loren J. Samons II.

p. $\mathrm{cm}$.

Includes bibliographical references and index.

ISBN o-520-23660-2 (cloth : alk. paper).

I. Democracy-History. 2. Direct democracy-

Greece-Athens. 3. Republicanism-United States-

History. 4. Representative government and representation-United States. 5. Political culture-United

States-History. 6. United States-Civilization-Greek influences. I. Title.

$\mathrm{JC}_{42 \mathrm{I}} \mathrm{S}_{32} 2004$

321.8-dc22 2004008500

Manufactured in the United States of America

$\begin{array}{llllllllll}\text { I3 } & \text { I2 } & \text { II } & \text { IO } & 09 & 08 & 07 & 06 & 05 & 04\end{array}$

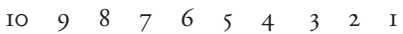

The paper used in this publication is both acid-free and totally chlorine-free (TCF). It meets the minimum requirements of ANSI/NISO Z39.48-I992 (R I997) (Permanence of Paper). 
To Jim and Brendan 
This page intentionally left blank 
For it is not at all pleasant to rail at incurable practices and errors that are far developed, though sometimes it is necessary.

THE ATHENIAN

Plato, Laws 660c-d (trans. Thomas L. Pangle)

BOSWELL: So, Sir, you laugh at schemes of political improvement?

JOHNSON: Why, Sir, most schemes of political improvement are very laughable things.

s. JOHNSON Boswell's Life of Johnson

... democracy means simply the bludgeoning of the people by the people for the people.

O. WILDE

Soul of Man under Socialism

. . . a state in which the mass of citizens is free to do whatever it pleases or takes into its head is not a democracy [but rather mob-rule]. But where it is both traditional and customary to reverence the gods, to care for our parents, to respect our elders, to obey the laws, and in such a community to ensure that the will of the majority prevails - this situation it is proper to describe as a democracy.

POLYBIUS 6.4

(trans. Ian Scott-Kilvert)

SOCRATES: What device could we find to make our rulers, or at any rate the rest of the city, believe us if we told them a noble lie, one of those necessary untruths of which we have spoken? . . . Can you suggest any device which will make our citizens believe this story?

GLAUCON: I cannot see any way to make them believe it themselves, but the sons and later generations might, both theirs and those of other men.

PLATO

Republic $414 b-c, 415 c-d$ (trans. G. M.A. Grube, adapted)

MENE, MENE, TEKEL, UPHARSIN.

DANIEL 5:25 
This page intentionally left blank 